\title{
A hímvessző bőrének helyreállítása szklerotizáló lipogranuloma okozta deformitás miatt
}

\author{
Murányi Mihály dr. - Farkas Antal dr. - Kiss Zoltán dr. \\ Drabik Gyula dr. - Flaskó Tibor dr. \\ Debreceni Egyetem, Általános Orvostudományi Kar, Urológiai Tanszék, Debrecen
}

\begin{abstract}
Bevezetés: A hímtag körméretének növelése érdekében, az annak bőre alá bejuttatott zsírnemú anyag szklerotizáló lipogranulomát okoz. Hazánkban a szklerotizáló lipogranuloma okozta hímvessző-deformitások kezelésének legelterjedtebb módszere a két ülésben végzett bőrpótlás. Ennek ellenére a magyar nyelvű szakirodalomban kevés adat áll rendelkezésre a kétüléses mútét eredményességéről és várható szövődményeiről.

Célkitüzés: Tanulmányunkban a szklerotizáló lipogranuloma okozta deformitások miatti - két ülésben végzett - hímvesszőbőr-helyreállítással szerzett tapasztalatainkról, a mútét után kialakuló szövődményekről számolunk be retrospektív adatgyújtés alapján.

Módszer: 2008. március 1. és 2020. március 1. között a Debreceni Egyetem Urológiai Klinikáján 17 betegen végeztünk kétüléses hímvesszőboor-helyreállító mútétet. A szklerotizáló lipogranuloma által érintett bőrt teljes mértékben eltávolítottuk, majd a lecsupaszított hímtagot a herezacskó elülső felszínén kialakított subcutan csatornába helyeztük. A második ülés során a herezacskó bőre alá ültetett hímvesszőt felszabadítottuk.

Eredmények: A Clavien-Dindo-beosztás szerint az első ülés után három, a második ülés után egy I. gradusú szövődmény alakult ki; II-V. gradusú szövődményt nem figyeltünk meg. Azon 9 beteg közül, akik mindkét ülésen átestek, 7 beteg elégedett volt a beavatkozás eredményével, 2 beteg korrekciós mútéten esett át fél és 9 évvel a második ülés után. A 8 beteg közül, akik csak ez első ülést vállalták, egy korrekciós mütét történt 4 hónappal a műtét után.

Következtetés: A hímvessző szklerotizáló lipogranulomája esetén az érintett bőrterület kimetszése után hímvesszőbőrhelyreállítás szükséges. A herezacskó-bőrlebeny alkalmazásának előnye, hogy a herezacskó színe és elaszticitása a hímvesszőbőréhez hasonló, a tapintás- és erogén érzet megmarad. A kétüléses hímvesszőbőr-helyreállítás kevés szövődménnyel, plasztikai sebészeti jártasság nélkül elvégezhető.
\end{abstract}

Orv Hetil. 2021; 162(35): 1413-1417.

Kulcsszavak: szklerotizáló lipogranuloma, vaselinoma, paraffinoma, hímvesszőbőr-rekonstrukció

\section{Staged penile skin reconstruction for sclerosing lipogranuloma}

Introduction: Subcutaneous injection of liquid fatty materials to enhance penile girth induce sclerosing lipogranuloma of the penis. In spite of its well known severe consequences there has been a persistent use of this practice in non-medical circumstances.

Objective: The aim of this paper is to present our observations with staged penile skin reconstruction for sclerosing lipogranuloma and to evaluate postoperative complications in a retrospective manner.

Method: Between 2008 and 2020, 17 patients underwent surgery to treat sclerosing lipogranuloma of the penis by staged penile skin reconstruction at our department. Complete exscision of the involved tissue was performed, then the denuded penile shaft was inserted into a subcutaneous channel on the anterior side of the scrotum during the first stage. The second stage of reconstruction consisted of releasing the penile shaft from the scrotum. The second stage was performed merely on 9 in 17 patients.

Results: According to the Clavien-Dindo classification system, 3 grade I and 1 grade I complications occurred in the postoperative period after the first and second stage, respectively. Grade II-V complications were not observed. 7 of 9 patients who underwent both stages were satisfied with the final result, 2 patients had minor correction surgery 6 months and 9 years following the second stage. 1 of 8 patients who underwent only the first stage had minor correction surgery 4 months following the operation. 
Conclusion: In case of sclerosing lipogranuloma of the penis, excision of the affected tissue and reconstruction of the penile skin are indicated. Advantages of using scrotal skin flaps are that colour and elasticity of the scrotal skin are similar to penile skin, erogenous sensation of the scrotal flap remains intact. Applying staged penile skin reconstruction with scrotal skin flap has the advantage of few postoperative complications and it is easy to perform.

Keywords: sclerosing lipogranuloma, vaselinoma, paraffinoma, penile skin reconstrucion

Murányi M, Farkas A, Kiss Z, Drabik Gy, Flaskó T. [Staged penile skin reconstruction for sclerosing lipogranuloma]. Orv Hetil. 2021; 162(35): 1413-1417.

(Beérkezett: 2021. január 17.; elfogadva: 2021. március 1.)

\section{Rövidítés}

$\mathrm{MR}$ = mágneses rezonancia

A szklerotizáló lipogranuloma a szövetek közé bejuttatott zsírnemú anyag következtében kialakuló idegen test típusú, krónikus granulomatosus reakció [1]. A hímveszsző bőre alá a penis körméretének növelése érdekében bejuttatott vazelin, paraffin és egyéb zsírnemú anyag hasonló reakciót vált ki. A nemzetközi irodalomban a kórkép megnevezésére a szklerotizáló lipogranulomán kívül a bejuttatott anyagra utalva a vaselinoma, paraffinoma, oleogranuloma, siliconoma és liponecrosis elnevezésekkel is találkozhatunk [2]. A folyamat súlyos, akár a hímvesszőbőr elhalásával járó szövődményei jól dokumentáltak [3]. Ennek ellenére a testmódosítás ezen illegális módja továbbra is népszerú nem orvosi körülmények között, különösen Délkelet-Ázsiában és Kelet-Európában. A gyakorlat Magyarországon is jelentős probléma [4]. Egy közelmúltban megjelent tanulmány összegzése alapján az angol nyelvű szakirodalomban Korea és Bulgária után Magyarországról származik a harmadik legtöbb közölt eset [5]. Tanulmányunkban a szklerotizáló lipogranuloma okozta deformitások miatt két ülésben végzett hímvesszőbőr-helyreállítással szerzett tapasztalatainkról, a műtét után kialakuló szövődményekről számolunk be retrospektív adatgyújtés alapján.

\section{Betegek és módszerek}

2008. március 1. és 2020. március 1. között a Debreceni Egyetem Urológiai Klinikáján 17 betegen végeztünk kétüléses hímvesszőbőr-helyreállító műtétet. A betegek átlagéletkora 35,3 29,5 év volt. A vazelin hímvesszőbőrbe fecskendezése az első ülés előtt átlagosan 2,4 (0,259) évvel történt. 14 betegnek nem volt társbetegsége; egy-egy esetben szívritmuszavar, cukorbetegség és pánikbetegség szerepelt az anamnézisben. A lipogranuloma 5 esetben csak a hímvessző bőrére korlátozódott, 1 betegen a szeméremdomb böre alá is beterjedt, míg 11 esetben a szeméremdomb és a herezacskó is érintett volt. 1 betegen a lipogranuloma subcutan göbként volt tapintható, a felette elhelyezkedő bőr ép volt; 4 betegnél a hímvesszőbőrbőr elvékonyodását és sárgás elszíneződését észleltük; 8 beteg hímvesszőjén fekélyek jelentkeztek (1. ábra); négy betegnél pedig bőrelhalás is kialakult.

A hímvesszőboor-helyreállítás első ülését 14 esetben spinalis érzéstelenítésben, 3 esetben általános érzéstelenítésben végeztük. A szklerotizáló lipogranuloma által érintett bőrt teljes mértékben eltávolítottuk, amennyiben a folyamat a szeméremdombot vagy a herezacskót is érintette, az itt elhelyezkedő lipogranulomát is kimetszettük (2. és 3. ábra). Az esetek döntő többségében a vazelint a dartos fascia rétegébe adták, ezért a hímveszszőbőr kimetszése a Buck-fascia és a dartos fascia határán haladva történt. A lecsupaszított hímtagot a herezacskó

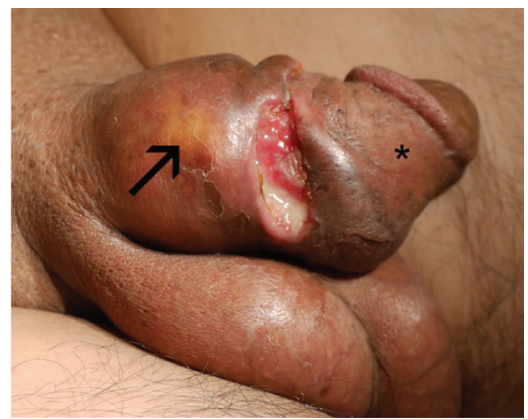

1. ábra

A hímvessző teljes hosszát érintő szklerotizáló lipogranuloma A csillaggal jelölt területen a lipogranuloma fölötti bőr megkí mélt, a nyíllal jelölt területen viszont elvékonyodott, sárgás elszíneződés látható. A hímvessző középső részén fekély látható

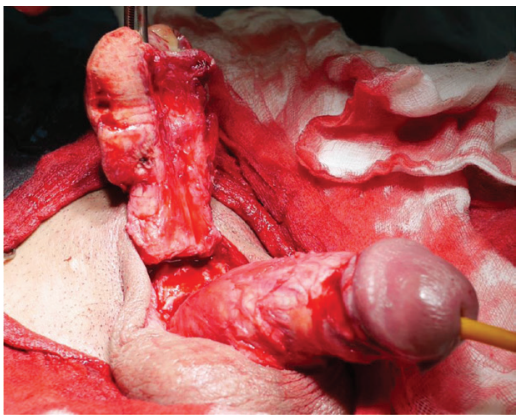

2. ábra $\quad$ A szklerotizáló lipogranuloma által érintett hímvesszőboor eltávolítása után a szeméremdomb szövetébe terjedő granuloma is eltávolításra kerül 


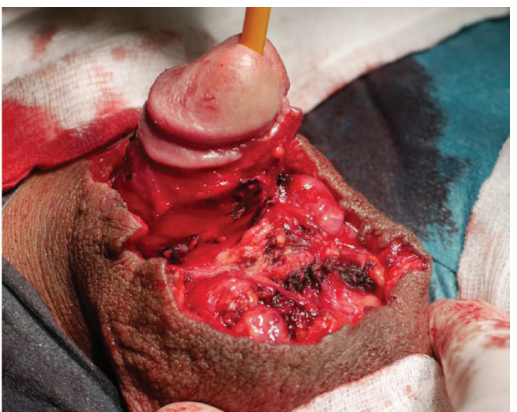

3. ábra

A herezacskó elülső felszínét érintő szklerotizáló lipogranuloma eltávolítása

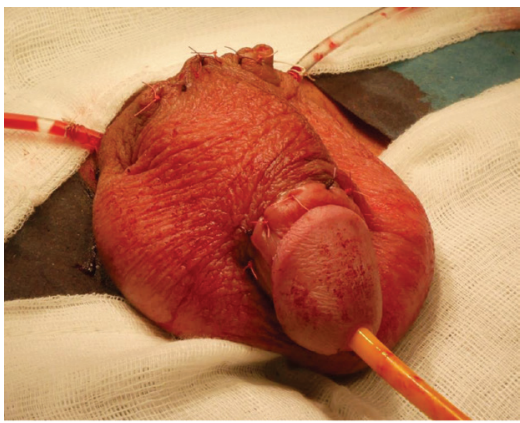

4. ábra

Az első ülés utáni állapot. A herezacskóba fektetett hímvesszô mellett két dréncső látható

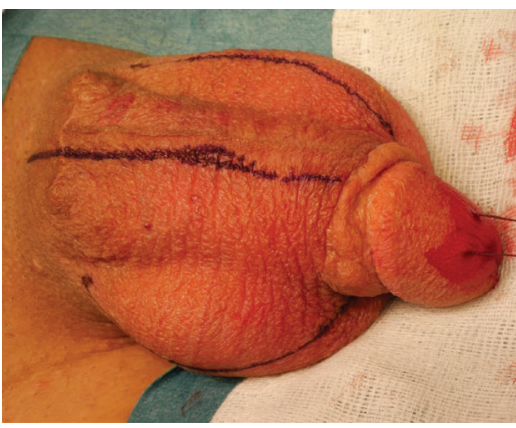

5. ábra

A második ülés elején a hímvessző körfogatának megfelelő szé lességű herezacskóbőrt jelölünk ki, melynek vonalában végezzük a bemetszést

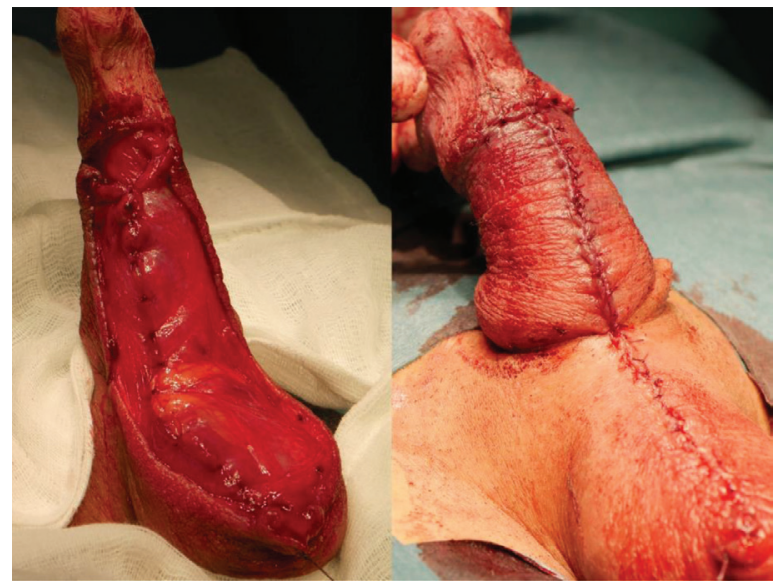

6. ábra

A hímvessző ventralis oldalán zárjuk a herezacskó-bőrlebenyt, egyúttal a scrotumot is zárjuk

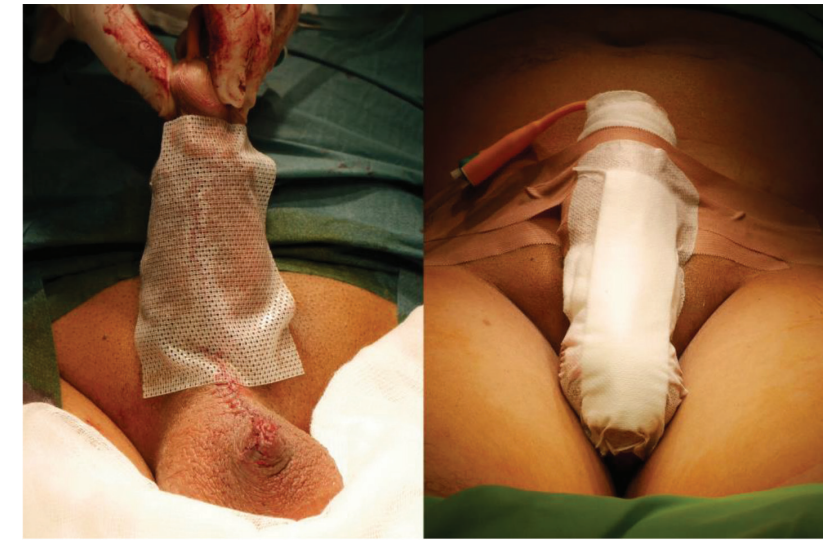

7. ábra

A második ülés végén a hímvesszőt kenőcsös kötszerrel fedjük, majd a hasra fektetve rögzítjük

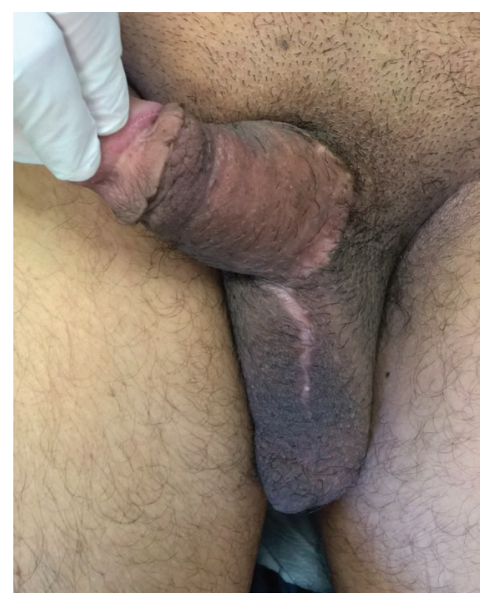

8. ábra $\mid$ A második ülés után 4 hónappal

elülső felszínén kialakított subcutan csatornába helyeztük. A mútét végén 2 beteg kivételével dréncsövet helyeztünk be (4. ábra). Az eltávolított szövetet minden esetben kórszövettani vizsgálatra küldtük.

A második ülés során a herezacskó bőre alá ültetett hímvesszőt felszabadítottuk (5-7. ábra). A 17 betegből mindössze 9 beteg esetén történt meg a második ülés is, az első ülés után átlagosan 11,2 (3-35) hónappal. 8 beteget spinalis érzéstelenítésben, 1 beteget pedig általános érzéstelenítésben operáltunk. 2 beteg kivételével dréncsövet nem helyeztünk be. A mútétek után egy hónappal járóbeteg-szakrendelés keretén belül a panaszok kikérdezésével és fizikális vizsgálattal kontrolláltuk a betegeket (8. ábra).

\section{Eredmények}

Az átlagos mútéti idő az első ülés esetén 116,6 \pm 38,6 perc, míg a második ülésnél $75,3 \pm 14,1$ perc volt. A mútét utáni ápolási napok száma az első és második ülés után 3,8 $\pm 1,4$ nap és $2,9 \pm 0,8$ nap volt. A szövettani vizsgálat minden esetben idegen test típusú óriássejtekkel, granulomatosus gyulladással, vacuolumokkal szab- 
dalt kötőszövettel jellemezhető szklerotizáló lipogranulomát igazolt. Az első ülés után a Clavien-Dindo-beosztás alapján három I. gradusú szövődmény alakult ki. A hazabocsátást követően mindhárom esetben sebgyógyulási zavar alakult ki, mely konzervatív terápiára meggyógyult. II-V. gradusú szövődményt nem figyeltünk meg. A második ülés után a Clavien-Dindo-beosztás szerint egy I. gradusú szövődményt figyeltünk meg. Hazabocsátást követően a hímvessző ventralis részén lévő varrat $1 \mathrm{~cm}$ hosszan szétvált, majd konzervatív kezelésre meggyógyult. II-V. gradusú szövődményt nem figyeltünk meg. Vérátömlesztést igénylő vérzés, húgycsősérülés, a dorsalis éridegköteg sérülése, heresérülés a mütétek során nem alakult ki. Makkérzészavarról vagy merevedési zavarról a betegek egyik ülés után sem számoltak be.

Azon 9 beteg közül, akik mindkét ülésen átestek - a második ülés után számított átlagosan 22,0 \pm 11,9 hónap utánkövetési idő elteltével -, 7 beteg elégedett volt a beavatkozás eredményével. 1 esetben a második ülés után fél évvel spinalis érzéstelenítésben dorsalis incisiót és hegkimetszést végeztünk, mivel a hímvessző méretéhez képest kissé hosszabb rekonstruált bőr distalis része a makkra ráborulva hegesen beszúkült. 1 beteg a második ülés után 9 évvel azzal a panasszal jelentkezett, hogy merevedés során a hímvessző ventralis oldalán feszülést tapasztal. Az ő esetében a penoscrotalis áthajlásban a Heineke-Mikulicz-alapelvet alkalmazva haránt bőrmetszés után hegkimetszést és hosszanti bőrzárást végeztünk spinalis érzéstelenítésben.

A 8 beteg közül, akik csak ez első ülést vállalták, 1 beteg kontrollvizsgálatra egyáltalán nem jött el. 7 beteg a mütét utáni kontrollvizsgálaton megjelent, de a második ülés egyeztetésére már nem jött el. Közülük átlagosan 3,7 $\pm 2,6$ hónap utánkövetés alatt egy korrekciós mütétet végeztünk. Az ő esetében a mútét után négy hónappal a szeméremdomb területén tapintott residualis lipogranuloma eltávolítását végeztük spinalis érzéstelenítésben.

\section{Megbeszélés}

Zsírnemú készítmény külső nemi szervekbe történő injektálásáról először Robert Gersuny számolt be 1899ben. Bilateralis orchiectomia után a herék pótlása céljából paraffint adott a herezacskóba [6]. Később egyéb területen is - emlőpótlás, arcdeformitások kezelése - kipróbálták az eljárást. A kezdeti ígéretes eredmények után azonban csakhamar kiderült, hogy a subcutan szövetekbe kívülről bejuttatott zsírnemú anyag súlyos szövődményekkel jár. Hímvessző-deformitás, -fájdalom, -duzzanat, -fekély, gennyes váladékozás, -bőrelhalás alakulhat ki, de nem ritka a fitymaszúkület, a hímvesszőgörbület, a fájdalmas közösülés és a közösülési képtelenség sem [3, 7]. Emiatt a hasonló eljárások kiszorultak az orvosi gyakorlatból [5]. Számos országban - köztük Magyarországon is - azonban nem orvosi keretek között, akár öninjekciózás formájában, az eljárás fennmaradt. Mivel a vazelin hímvesszőbe juttatása illegális, a betegek jelentős része panaszok kialakulása esetén nem fordul orvoshoz. Ezért a szövődmények arányát és súlyosságát nehéz pontosan megbecsülni. A Magyarországon található hat legnagyobb börtönben Rosecker és mtsai által végzett kérdőíves felmérés alapján a vazelin-öninjekciózáson átesett férfiak 15,1\%-a volt elégedetlen a hímvessző méretével és 28,8\%-a elégedetlen annak alakjával a beavatkozás után. Merevedési zavar 21,4\%-ban, hímvesszőfekély pedig 52,6\%-ban alakult ki. Összességében 29,1\%-uk bánta meg később a vazelinbefecskendezést [4].

A kórisme felállításának legfontosabb lépése a kórelőzmény felvételén túl a külső nemi szervek megtekintése és tapintása. Ennek során rögzíteni kell a hímvesszőbőr állapotát. Egyes esetekben csak a dartos fascia érintett, a lipogranuloma okozta göbök fölött az ép bőr könnyen elmozdítható. Gyakran azonban a bőr is érintett, ilyenkor a bőr tömött, az alatta lévő szövetektől nem mozdítható el, és sárgás elszíneződés is kialakul. Későbbi stádiumban nehezen vagy egyáltalán nem gyógyuló, váladékozó fekélyek, súlyos esetben bőrelhalás látható. A folyamat kiterjedésének megítélése miatt fontos a szeméremdomb és a herezacskó áttapintása is, hiszen a lipogranuloma a hímvesszőbőrön kívül ezeket a területeket is érintheti. Korábbi közlemények leírták a hímvesszőbőrt érintő szklerotizáló lipogranuloma ultrahangos és MRvizsgálat során talált jellegzetességeit, a képalkotó vizsgálatok azonban kevés gyakorlati jelentőséggel bírnak a diagnosztikában $[5,8]$.

A hímvesszőbőr szklerotizáló lipogranulomájának kezelése sebészi [7]. Az érintett bőrterület maradéktalan eltávolítása után a hímvesszőbőr helyreállítása szükséges a megmaradt hímvesszőbőr, herezacskó-bőrlebeny vagy nem genitalis félvastag bőr segítségével. Amennyiben a szklerotizáló lipogranuloma a hímvessző kis részét érinti, a hímvessző fedése megoldható a maradék hímvesszőbőrrel $[2,7]$. A teljes hímvesszőbőrhiány pótolható, a leggyakrabban a combról eltávolított, félvastag bőr átültetésével [3]. Szintén teljes bőrhiány esetén alkalmazható a herezacskó-bőrlebennyel történő fedés. Ez utóbbinak számos különböző technikája ismert. Shin és mtsai fordított $\mathrm{V}$ alakú anasztomózissal kialakított bilateralis herezacskólebennyel végzett hímvesszőbőr-rekonstrukcióról számoltak be 14 eset kapcsán. 3 betegnél figyeltek meg sebgyógyulási zavart, de a kialakított bőrlebeny minden esetben megmaradt [9]. Bajory és mtsai 2013ban közölték saját módosított, nyeles herezacskó-bőrlebennyel végzett együléses mütéttechnikájuk eredményeit. Az ezzel a technikával operált 12 beteg közül 3 esetben alakult ki a bőrlebeny széli részén elhalás, mely miatt necrectomiát végeztek [10]. Kim és mtsai 2014ben 5 eset kapcsán számoltak be mütéttechnikájukról, melyben a hímvesszőbőr rekonstrukcióját bipedicularis herezacskó-bőrlebennyel oldották meg, melyet kiegészítettek a penis dorsalis oldalán egy V-Y bőr plasztikával, valamint a ligamentum suspensorium penis részleges átvágásával. 5 betegük közül egyben alakult ki reoperációt 
igénylő sebszétválás, a többi beteg szövődménymentesen meggyógyult [11].

Hazánkban Kelemen és mtsai végeztek elsőként kétüléses bőrpótlást herezacskó-bőrlebennyel [7]. Jelen dolgozatunkban az általuk népszerúsített mütéti technikával végzett műtéteink eredményeit közöljük. A műtéttechnika a nemzetközi irodalomban Cecil-féle kétüléses mütétként ismert [2]. Magyarországon a szklerotizáló lipogranuloma okozta hímvessző-deformitások kezelésének legelterjedtebb módszere a két ülésben végzett bőrpótlás. Rutinműtétnek tekinthető, ennek ellenére a magyar nyelvü szakirodalomban kevés adat áll rendelkezésre a mưtét eredményességéról és várható szövődményeiről. Kelemen és mtsai 2006-ban megjelent eredeti tanulmányukban 16 beteg közül 4 esetben alkalmazták a kétüléses technikát. A herezacskóba ültetés után 1 betegen végeztek sebszélfelfrissítést sebszétválás miatt [7]. Az angol nyelvü szakirodalomban Nyirády és mtsai 4, míg Bajory és mtsai 20 beteg kétüléses mütétének eredményeiről számoltak be $[1,10]$. Az utóbbi tanulmányban a 20 betegből 5 esetben alakult ki a második ülés után bőrelhalás [10].

\section{Következtetés}

A herezacskó-bőrlebennyel végzett rekonstrukciók szövődményarányát nehéz összehasonlítani, mivel mind az együléses, mind a kétüléses mútétek eredményeit bemutató közlemények betegszáma alacsony. A rendelkezésre álló adatok alapján együléses mütét után a betegek 2025\%-ánál számíthatunk sebgyógyulási zavarra, sebszétválásra vagy bőrelhalásra. A tanulmányunkban szereplő 17 beteg közül négynél $(23,5 \%)$ - háromnál az első, egyben a második ülés után - alakult ki sebgyógyulási zavar vagy sebszétválás a mútét utáni időszakban. Ezek alapján feltételezhető, hogy az egy- és kétüléses bőrpótlás esetében hasonlóan alacsony, mütét utáni szövődményarány várható.

A herezacskóbőr lebenyként történő alkalmazásának a félvastag bőr átültetéséhez képest több előnye van. A mütét nem igényel speciális eszközöket, a félvastag bőr eltávolításához szükséges dermatomot. A herezacskó színe és elaszticitása a hímvesszőbőréhez hasonló, emellett a lebeny tapintás- és erogén érzéke megmarad. Hátránya azonban, hogy a herezacskó szőrös, és mérete korlátozott. A herezacskó jelentős részét érintő szklerotizáló lipogranuloma esetén nem alkalmas a bőrpótlásra.

A kétüléses hímvesszőbőr-helyreállítás előnye az együléses mütétekkel szemben az, hogy a műtét egyszerü, plasztikai sebészeti jártasságot nem igényel. A műtét hátrányai a kétüléses jellegből adódnak. A két ülés kétszeres kórházi tartózkodást és kétszeres mútéti rizikót jelent. A hímvessző a két ülés között természetellenes helyzetben van. Magas a betegek első ülés utáni lemorzsolódási aránya. A tanulmányunkban szereplő betegek majdnem fele nem jelentkezett a második ülésre. Még ha elégedettek voltak is az első ülés utáni eredménnyel, az ő esetükben nem beszélhetünk teljes hímvesszőbőr-helyreállításról.

Anyagi támogatás: A közlemény megírása anyagi támogatásban nem részesült.

Szerzői munkamegosztás: M. M.: A mütétek végzése, a mütéti képek elkészítése, a közlemény megírásához szükséges szakirodalom áttekintése, a közlemény megírása. F. A., K. Z., D. Gy.: Mütétek végzése, a kézirat ellenőrzése. F. T.: Szakmai irányítás, a kézirat végső ellenőrzése. A cikk végleges változatát valamennyi szerző elolvasta és jóváhagyta.

Érdekeltségek: A szerzőknek nincsenek érdekeltségeik.

\section{Irodalom}

[1] Nyirády P, Kelemen Z, Kiss A, et al. Treatment and outcome of vaseline-induced sclerosing lipogranuloma of the penis. Urology 2008; 71: 1132-1137.

[2] Soebhali B. Penile self-injections for girth augmentation: treatment of complications. In: Martins FE, Kulkarni SB, Köhler TS. Textbook of male genitourethral reconstruction. Springer Nature Switzerland AG, Cham, 2020; pp. 783-794.

[3] Svensøy JN, Travers V, Osther PJ. Complications of penile selfinjections: investigation of 680 patients with complications following penile self-injections with mineral oil. World J Urol. 2018; 36: 135-143.

[4] Rosecker Á, Bordás N, Pajor L, et al. Hungarian “jailhouse rock": incidence and morbidity of vaseline self-injection of the penis. J Sex Med. 2013; 10: 509-515.

[5] Downey AP, Osman NI, Mangera A, et al. Penile paraffinoma. Eur Urol Focus 2019; 5: 894-898.

[6] Gersuny R. About a subcutaneous prosthesis. [Uber eine subcutane Prothese.] Ztschr f Heilk. 1900; 21: 199. [German]

[7] Kelemen Zs, Nyirády P, Bánfy G. Penile girth enhancement with vezelin - consequences and its management. [A hímvessző vastagítása vazelinnel - követkemények és azok ellátása.] Magy Urol. 2006; 18: 16-27. [Hungarian]

[8] Francis J, Poh Choo Choo A, Wansaicheong Khin-Lin G. Ultrasound and MRI features of penile augmentation by "Jamaica oil" injection. A case series. Med Ultrason. 2014; 16: 372-376.

[9] Shin YS, Zhao C, Park JK. New reconstructive surgery for penile paraffinoma to prevent necrosis of ventral penile skin. Urology 2013; 81: 437-441.

[10] Bajory Z, Mohos G, Rosecker A, et al. Surgical solutions for the complications of the vaseline self-injection of the penis. J Sex Med. 2013; 10: 1170-1177.

[11] Kim SW, Yoon BI, Ha US, et al. Treatment of paraffin-induced lipogranuloma of the penis by bipedicled scrotal flap with Y-V incision. Ann Plast Surg. 2014; 73: 692-695.

(Murányi Mihály dr.,

Debrecen, Nagyerdei krt. 98., 4032 e-mail: muranyi.mihaly@med.unideb.hu) 